DOI: 10.17707/AgricultForest.64.4.28

Gordan S. KARAMAN ${ }^{1}$

\title{
FURTHER DATA ON PECULIAR SUBTERRANEAN FAUNA OF NIPHARGIDAE FAMILY IN GREECE (CONTRIBUTION TO THE KNOWLEDGE OF THE AMPHIPODA 306)
}

\section{SUMMARY}

The subterranean species Niphargus karkabounasi Ntakis et al., 2015 (Amphipoda, fam. Niphargidae) was known from type-locality only (AgioiTheodoroi, Korinthos, Peloponnese, Greece). This species is established now in some other localities in Greece, partially redescribed, figured and variability of some of its taxonomical characters are presented.

The new peculiar species, Niphargus pararhodi, sp. n. is described from the spring-brook along Gadouras River (Apolona region, Greece) based on one adult male and its taxonomical position regarding other species from Greece is discussed.

Keywords: Amphipoda, Niphargus karkabounasi, pararhodi, taxonomy, subterranean waters, Greece.

\section{INTRODUCTION}

The fauna of the subterranean family Niphargidae in Greece has been studied by various scientists and numerous new taxa were discovered and described. Our recent study of this family in Greece show the astonishing variety of taxa: 3 genera and over 20 species and subspecies, despite only partially investigated this fauna in Greece. During present investigation of the material collected in Greece by several scientists from Italy and Holland, new localities and variability of one known endemic species are presented and description of one peculiar new species of the genus Niphargus Schiödte, 1849 is described and figured.

\section{MATERIAL AND METHODS}

The collected specimens were preserved in 70\% ethanol and sent us for determination. The specimens were dissected using a WILD M20 microscope and drawn using camera lucida attachment. All appendages were temporarily submersed in the mixture of glycerin and water for study and drawing. The appendages were transferred to Liquid of Faure on permanent slides. All illustrations were inked manually. Some morphological terminology and setal formulae follow G. Karaman's terminology (Karaman, G., 1969; 2012) regarding the last mandibular palpus article $[\mathrm{A}=$ setae on outer face; $\mathrm{B}=$ setae on inner face;

\footnotetext{
${ }^{1}$ Gordan S. Karaman (corresponding author: karaman@t-com.me), Montenegrin Academy of Sciences and Arts, Podgorica, MONTENEGRO

Notes: The author declare that they have no conflicts of interest. Authorship Form signed online.
} 
$\mathrm{D}=$ lateral marginal setae; $\mathrm{E}=$ distal long setae $]$ and propodus of gnathopods 1 and 2 [S= corner S-spine; $\mathrm{L}=$ lateral slender serrate L-spines; $\mathrm{M}=$ facial $\mathrm{M}$-setae; $\mathrm{R}=$ subcorner R-spine on inner face]. Terms "setae" and "spines" are used based on its shape, not origin. Some ecological data of samples-localities of Greece have been published by Pesce \& Maggi (1983).

The research in this work is based on the classic morphological, ecological and zoogeographical studies.

\section{TAXONOMICAL PART}

\section{Family NIPHARGIDAE}

\section{NIPHARGUS KARKABOUNASI Ntakis, Anastasiadou, Zakšek \& Fišer 2015 Figures 1-3}

Niphargus karkabounasi Ntakis, Anastasiadou, Zakšek \& Fišer 2015: 37, figs. 2B, 7-10.

\section{MATERIAL EXAMINED: GREECE}

G-78= Attica, road Korinthos-Athens near Megara, water temp. $18.5^{\circ} \mathrm{C}, \mathrm{pH}$ 6.8, 2 exp. 3.3 mm; 9.5 .1977 (leg. Pesce, Maggi \& Miranda);

G-93= Attica, road Korinthos-Athens, nearly $4 \mathrm{~km}$ from Korinthos, well, water temp. $17.4^{\circ} \mathrm{C}, \mathrm{pH}$ 6.9; 17 small exp., 9.4.1978 (leg. Pesce \& Maggi);

G-94=Attica, road Korinthos-Athens, Agioi Theodoroi, water temp. $19.9^{\circ} \mathrm{C}$; pH 6.9; 6 exp., 9.4.1978 (leg. Pesce \& Maggi) (probably topotypic locality);

G-95 (S-6374) = Attica, road Korinthos-Athens, Megara, 2 wells, water temp. $16.9^{\circ} \mathrm{C}$, pH 6.9; 2 exp. 3 mm, 9.4.1978 (leg. Pesce \& Maggi);

G-96= Attica, road Korinthos- Athens, Megara, 2 wells, water temp. $16.9^{\circ} \mathrm{C}$, pH 6.9; one exp 3.4 mm; 9.4 .1978 (leg. Pesce, Maggi \& Silverii);

G-97=Nafplio (=Nauplion) (Argos), Peloponnese, 2 wells, water temp. 21.5 ${ }^{\circ} \mathrm{C}$, pH 6.8; one exp. $2.8 \mathrm{~mm}, 9.4 .1978$, (leg. Pesce, Maggi \& Silverii);

G-232= Skopelos island, Panormos (cca $250 \mathrm{~m}$ from the sea), 2 wells, water temp. $14.2^{\circ} \mathrm{C}$, pH 7.1, 6.7.1980, one damaged exp. $3.6 \mathrm{~mm}$ (leg. G. Pesce).

\section{DESCRIPTION}

Ntakis et al. (2015) described this species based on specimens from one locality [Agioi Theodoroi in Korinthos region, Greece]. The specimens from our new localities agree mainly with description of this species from type-locality, with some minor differences.

Female $4.0 \mathrm{~mm}$ with setose oostegites from G-93 (near Korinthos):

Metasomal segments 1-3 with 2-3 dorsoposterior setae each (fig. 2B). 


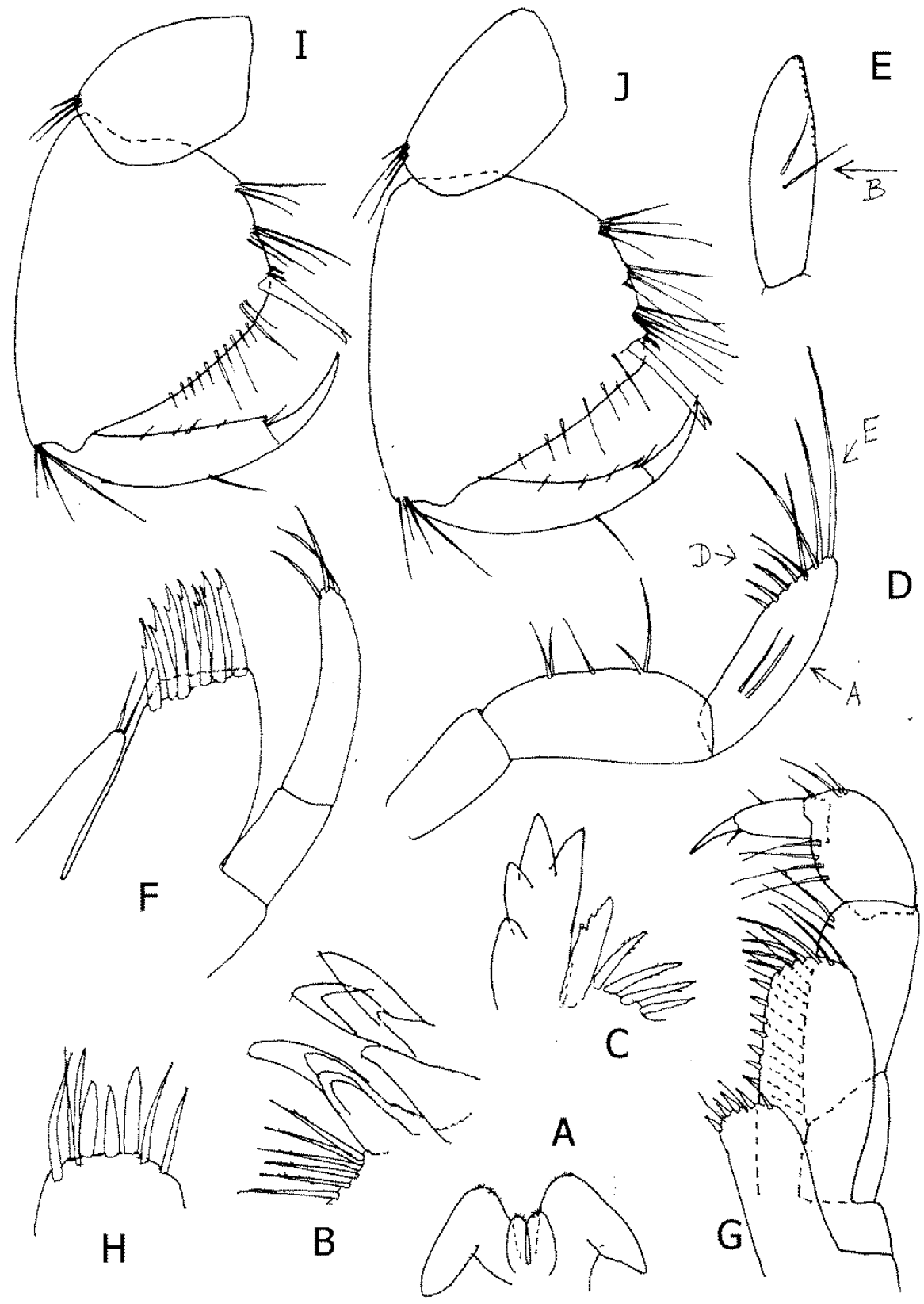

Fig. 1. Niphargus karkabounasi Ntakis et al., 2015, G-93, Korinthos, female 4.0 mm: $A=$ labium; $B=$ right mandible, incisor and lacinia mobilis; $C=$ left mandible: incisor and lacinia mobilis; $\mathrm{D}=$ mandibular palpus, outer face with $\mathrm{A}$, $\mathrm{D}$, E setae; $\mathrm{E}=$ last article of mandibular palpus, inner face with $\mathrm{B}$-setae; $\mathrm{F}=$ maxilla 1; $\mathrm{G}=$ maxilliped; $\mathrm{H}=$ inner plate of maxilliped; $\mathrm{I}=$ gnathopod 1 propodus, outer face; $\mathrm{J}=$ gnathopod 2 propodus, outer face. 


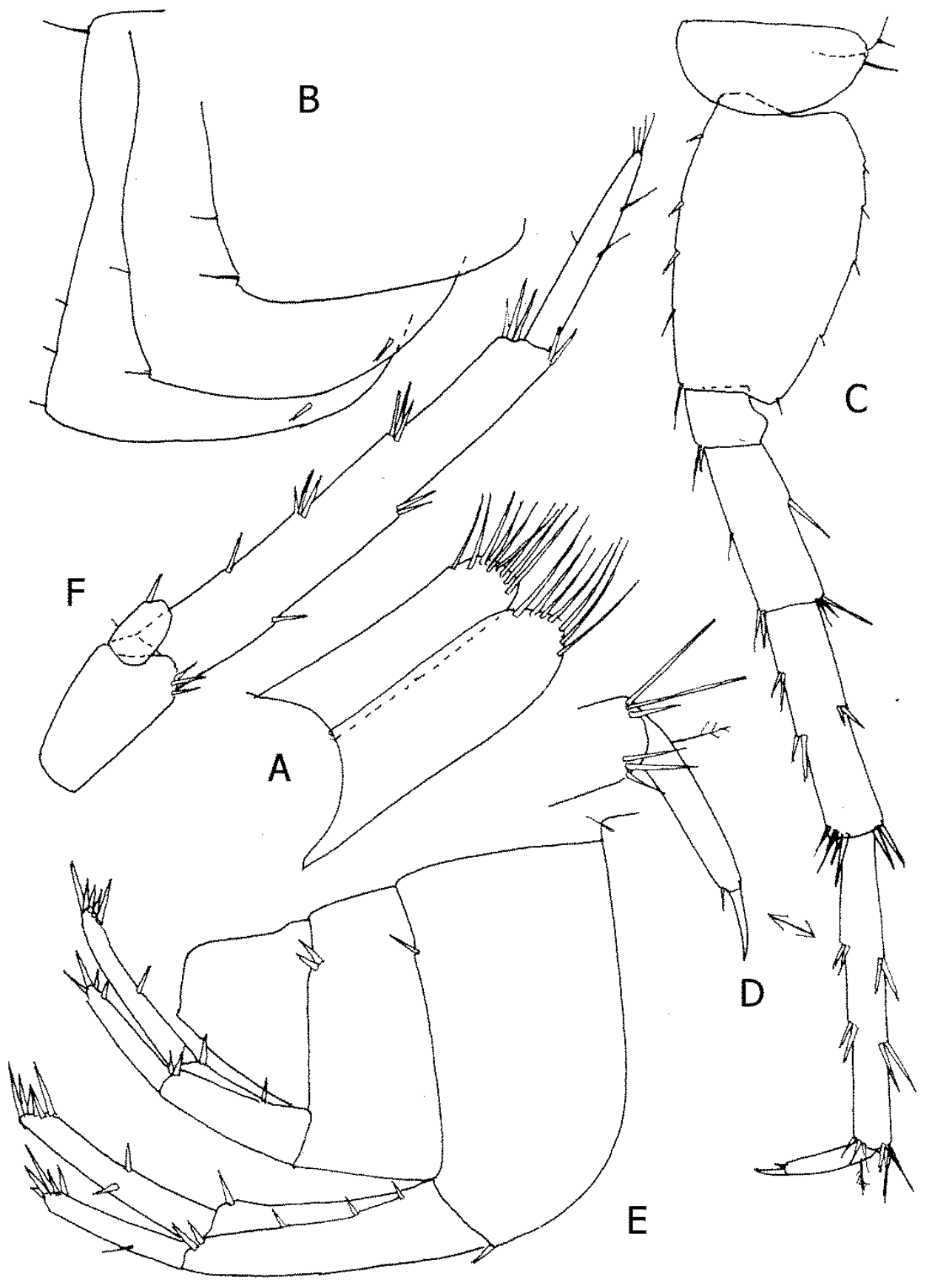

Fig. 2. Niphargus karkabounasi Ntakis et al., 2015, G-93, Korinthos, female 4.0 $\mathrm{mm}$ : $\mathrm{A}=$ maxilla $2 ; \mathrm{B}=$ epimeral plates $1-3 ; \mathrm{C}=$ pereopod $7 ; \mathrm{D}=$ dactylus of pereopod 7; $\mathrm{E}=$ urosome with uropods $1-2 ; \mathrm{F}=$ uropod 3 . 
Urosomal segment 1 on each dorsolateral side with one seta; urosomal segment 2 on each dorsolateral side with 2 spines; urosomal segment 3 naked (fig. 2E). Urosomal segment 1 at each ventroposterior corner with one short spine near basis of uropod 1 peduncle (fig. 2E).

Epimeral plates 1 and 2 obtusely angular, with slightly convex posterior margin bearing 1-2 lateral setae; epimeral plate 3 angular, but not pointed, with inclined or poorly convex posterior margin provided with 1-2 lateral setae; one ventral slender spine appears on epimeral plates 2 and 3 (fig. 2B).

Lateral cephalic lobes short, subrounded. Antenna 1 reaching half of bodylength, with progressively shorter peduncular articles 1-3; main flagellum consisting of 14 articles (most of them with one aesthetasc exceeding 2/3 of article itself (fig. 3C). Accessory flagellum short, 2-articulated, exceeding half of peduncular article 3 (fig. 3B).

Antenna 2 flagellum slender, longer than last peduncular article and consisting of 5 articles.

Labrum broader than long, convex distally (fig. 3A). Labium broader than long, inner lobes short, outer lobes subrounded (fig. 1A).

Mandibles with triturative molar. Left mandible: incisor with 5 teeth, lacinia mobilis with 4 teeth accompanied by 6 rakers (fig. 1B). Right mandible: incisor with 4 teeth, lacinia mobilis bifurcate, serrate, accompanied by 4 rakers (fig. 1C). Mandibular palpus 3-articulated: first article naked, second article with 5 strong setae (fig. 1D); third article subfalciform, as long as article 2 and provided with 5-6 strong D-setae and 3-4 long distal E-setae; 2 A-setae appear on outer face (fig. 1D) and $2 \mathrm{~B}$-setae are present on inner face (fig. 1E).

Maxilla 1: inner plate with 2 setae, outer plate with 7 spines provided with one strong lateral tooth each (fig. 1F); palpus 2-articulated, reaching tip of outer plate-spines and provided with 3 distal strong setae.

Maxilla 2 with nearly subequal both plates bearing distomarginal setae (fig. 2A).

Maxilliped: inner plate short, with 3-4 distal spines mixed with single setae, outer plate exceeding half of palpus article 2 and provided with 7-8 distolateral spines (fig. 1G); palpus article 4 with nail, one short seta is attached at inner margin near basis of the nail.

Coxae are short. Coxa 1 broader than long (ratio: 58:36) with subrounded ventroanterior corner and poorly concave ventral margin provided with 3 marginal setae (fig. 3D). Coxa 2 poorly broader than long (ratio: 55:53), with 3 ventral setae (fig. 3E). Coxa 3 nearly as long as broad, at margin with 2 setae (fig. 3F). Coxa 4 hardly broader than long (ratio: 64:60), with 2 ventral setae and without ventroposterior lobe (fig. 3G).

Coxa 5 rather shorter than coxa 4, bilobed, broader than long (ratio: 74:46), with 2 setae at posterior margin (fig. 3H). Coxa 6 is smaller than coxa 5, bilobed, broader than long (ratio: 62:37), with one posterior seta (fig. 3 I). Coxa 7 entire, broader than long (ratio: 63:30) with convex ventral margin and one posterior seta (fig. $3 \mathrm{~J})$. 

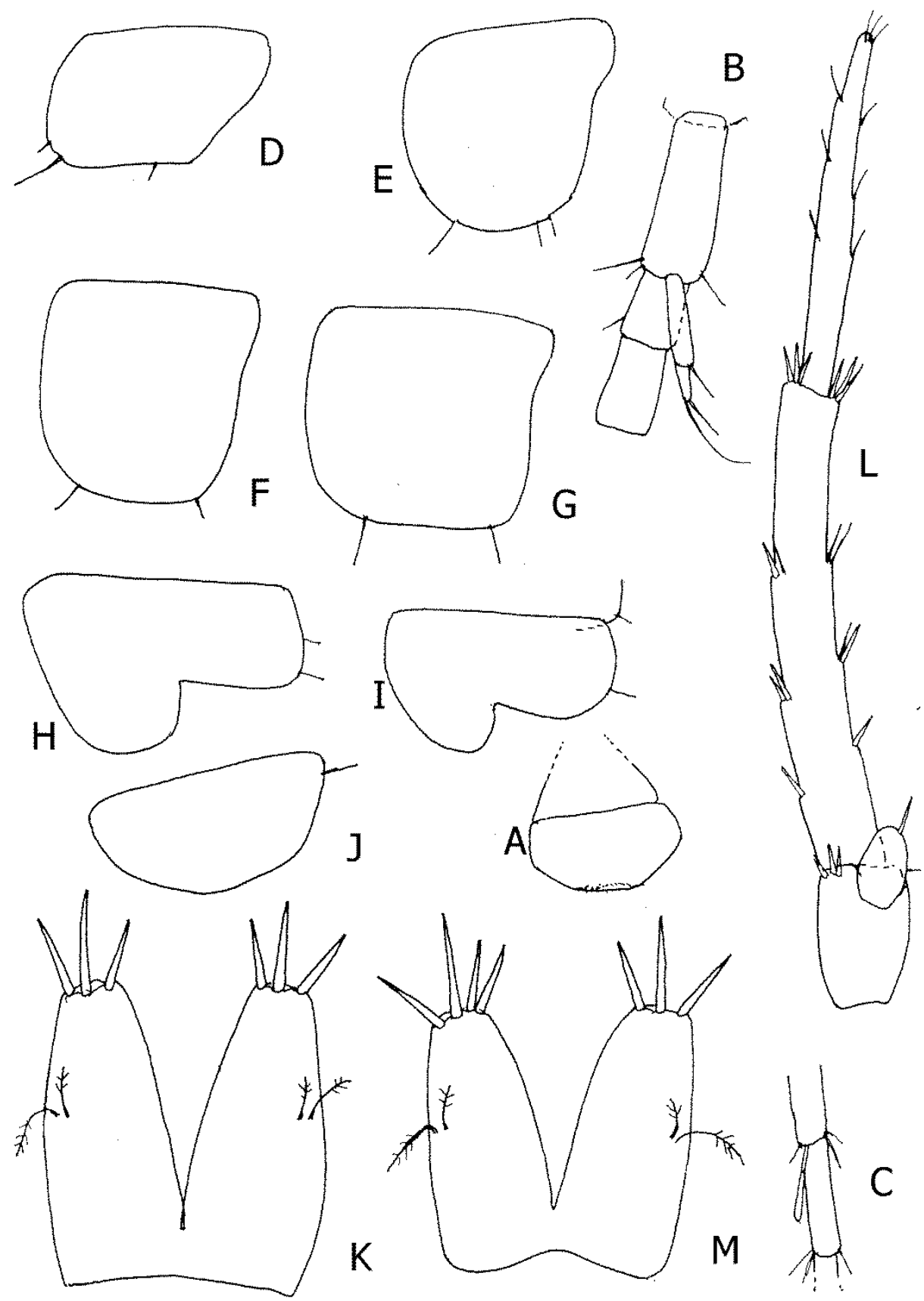

Fig. 3. Niphargus karkabounasi Ntakis et al., 2015, G-93, Korinthos, female 4.0 mm: A- labrum; $\mathrm{B}=$ accessory flagellum; $\mathrm{C}=$ aesthetasc on antenna $1 ; \mathrm{D}=$ coxa 1 ; $\mathrm{E}=\operatorname{coxa} 2 ; \mathrm{F}-\operatorname{coxa} 3 ; \mathrm{G}=\operatorname{coxa} 4 ; \mathrm{H}=\operatorname{coxa} 5 ; \mathrm{I}=\operatorname{coxa} 6 ; \mathrm{J}=\operatorname{coxa} 7 ; \mathrm{K}=$ telson.

Male 3.9 mm, G-94, Agioi Theodoroi: $\mathrm{L}=\operatorname{uropod} 3$; $\mathrm{M}=$ telson. 
Gnathopods 1-2 of moderate size, with propodus slightly larger than corresponding coxa. Gnathopod 1: article 3 at posterior margin with one bunch of setae; article 5 much shorter than propodus (ratio: 50:85), with 3 distal setae (fig. 1 I). Propodus trapezoid, longer than broad (ratio: 86:66), along posterior margin with 2 transverse rows of setae (fig. 1 I). Palm slightly convex, inclined nearly half of propodus-length, defined on outer face by one corer S-spine accompanied laterally by 2 L-spines and 2 facial M-setae, on inner face by one subcorner Rspine. Palm provided with setae of unequal length sitting mainly in distal part of palm. Dactylus reaching posterior margin of propodus and provided with one median seta at outer margin and several setae at inner margin (fig.1 I).

Gnathopod 2: article 3 at posterior margin with one bunch of setae; article 5 shorter than propodus (ratio: 50:82), with 4 distal setae (fig. 1J). Propodus trapezoid, almost of the same size of that in gnathopod 1, trapezoid, poorly longer than broad (ratio: 82:72), along posterior margin with 3 transverse rows of setae. Palm convex, inclined nearly to the half of propodus-length, defined on outer face by one S-spine accompanied laterally by one L-spine and one facial M-seta, on inner face by one subcorner R-spine. Palm provided with scarce number of setae. Dactylus reaching posterior margin of propodus and provided with one median seta at outer margin and several setae at inner margin (fig. 1J).

Pereopods 3-4 relatively slender; dactylus slender, at inner margin with one slender spine neat basis of the nail.

Pereopod 5 shorter than pereopod 6, both moderately slender, article 2 dilated but without ventroposterior lobe, along posterior margin appear several setae only; articles 4-6 along both margins with spines and setae; dactylus slender, at inner margin with slender spine near basis of the nail.

Pereopod 7: article 2 longer than broad (ratio: 80:48), at anterior margin with 5 single spine-like setae, along posterior convex margin with 5 short setae, ventroposterior lobe not distinctly developed. Articles 4-6 of unequal length (ratio: 46:64:83), along both margins with spines and single short setae (fig. 2C). Article 2 hardly shorter than article 6 (ratio: 80:83). Dactylus slender, remarkably shorter than article 6 (ratio: 33:83), at inner margin with one slender spine near basis of the nail, at outer margin with one median plumose seta (fig. 2D); nail shorter than pedestal (ratio: 18:50).

Pleopods 1-3 with 2 retinacula each; peduncles naked.

Uropod 1: peduncle with dorsoexternal row of spines, at dorsointernal margin appears distal spine only (fig. 2E); inner ramus shorter than peduncle, with 2 lateral and 5 distal short spines; outer ramus distinctly shorter than inner one, with one lateral short simple seta and 5 distal short spines.

Uropod 2: peduncle with lateral and distal spines; inner ramus with one lateral and 5 distal short spines (fig. 2E); outer ramus remarkably shorter than inner one, with 5 distal short spines.

Uropod 3 long and slender: peduncle rather longer than broad, with 3-4 distal spines; inner ramus very short, scale-like, much shorter than peduncle and provided with 0-1 lateral seta and one distal spine. Outer ramus 2-articulated: 
first article at outer margin with 3 groups of short spines, at inner margin with 4 bunches of spines, setae absent (fig. 2F); second article slender, reaching up to half of first article and provided with 2-3 lateral and 4 short distal simple setae.

Telson slightly longer than broad (ratio: 80:74), deeply incised, each lobe with 3 distal spines much shorter than half of telson-length, lateral and facial spines absent; a pair of plumose setae attached near the middle of outer margin of lobes (fig. 3K).

Coxal gills ovoid, relatively short. Oostegites broad, with setae at margins.

The males of locality G-93: similar to females, including uropods 1-3. Ntakis et al (2015) mentoned that males differs from females by elongated distal article of uropod 3 outer ramus, but on the figured uropod 3 of male and female it seems to be similar to each other. We observed also large variability of length of distal article of uropod 3 in females and males (reaching 30-50\% of first article).

The male of G-94 $(3.9 \mathrm{~mm})$ from Korinthos, Agioi Theodoroi: uropod 3 second article of outer ramus elongated, reaching nearly 70 percent of first article (fig. 3L). Uropod 3 in all other specimens of this locality like that in typical specimens (distal article reaching $1 / 3$ to $1 / 2$ of first article). Outer ramus of uropod 1 with 0-1 lateral simple seta. Uropod 2 outer ramus of variable length, but always distinctly shorter than inner one. Telson with 3-4 distal spines on each lobe, facial and lateral spines absent (fig. 3M).

Specimen $3.5 \mathrm{~mm}$ from Scopelos island (Aegean Sea, Greece) (G-232):

Partially damaged specimen (pereopods 5-7 are missing) is very similar to typical karkabounasi: telson with 3 distal spines on each lobe; epimeral plate 3 obtusely angular, uropods 1 and 2 with outer ramus much shorter than inner one; distal article of uropod 3 outer ramus reaching 2/5 of first article, propodus of gnathopods 1-2 of almost similar size and with strongly inclined palm.

\section{AFFINITY}

Niphargus karkabounasi is relatively small species, belonging to the group of Greek species with one seta on gnathopod`s dactylus. Within this group, partially reduced number of D-setae on mandible palpus is present in Niphargus lakusici G. Karaman 2017a, known from Crete Island.

$N$. lakusici is similar to $N$. karkabounasi also by shortened outer ramus of uropods 1 and 2, by similar shape of gnathopods and epimeral plates, pleopods, dactylus of pereopods 3-7, but differs from $N$. karkabounasi by short second article of uropod 3 outer ramus in males, by short inner plate of maxilliped provided with reduced number of distal spines, by short outer ramus of maxilliped, by lobed article 2 of pereopods 5-7, by presence of dorsointernal row of spine-like setae on uropod 1 peduncle, presence of lateral spines on lobes of telson.

As $N$. lakusici was described based on one male only, more detailed comparison with $N$. karkabounasi is not reasonable. Both taxa seems to be close to each other despite the geographical distances, and further study on new material of both taxa will show their real taxonomical relation. 
LOCUS TYPICUS: Agioi Theodoroi, Korinthos, Peloponnese, Greece. DISTRIBUTION: Greece, endemic.

\section{NIPHARGUS PARARHODI sp. n. \\ Figures 4-8}

\section{MATERIAL EXAMINED:}

No-11A. Spring-brook along river Goudouras (Gaidouras), Apollona region, Rhodos Island, Greece, 12.3.1973, male 8.2 mm (leg. J. Stock).

\section{DIAGNOSIS (male only).}

Body strong, metasomal segments with marginal setae, urosomal segments 1-2 with spine. Lateral cephalic lobes subrounded, eyes absent; maxilla 1 inner plate with 1-2 setae, outer plate with 7 spines bearing 1-5 small lateral teeth; maxilla 2 inner plate is smaller than outer one; maxilliped inner plate with 2 spines. Coxae relatively short, coxa 4 unlobed, coxa 5 smaller than coxa 4; epimeral plates pointed. Gnathopods 1-2 strong, with dactylus bearing a row of setae along outer margin; dactylus of pereopods 3-7 with one spine at inner margin; article 2 of pereopods 5-7 unlobed. Pleopods with 2 retinacula; uropod 1 with dorsointernal row of setae, rami equally long; uropod 2 inner ramus longer than outer one. Uropod 3 outer ramus with distal article relatively short. Telson with distal and mesial marginal spines.

DESCRIPTION: Male 8.2 mm (holotype): Body moderately slender, metasomal segments 1-3 with 2 stronger distoposterior setae accompanied by 2 shorter setae each (fig. 8C). Urosomal segment 1 and urosomal segment 2 on each dorsolateral side with one spine; urosomal segment 3 naked (fig. 8D). Urosomal segment 1 on each ventroposterior corner with one spine near basis of uropod 1 peduncle (fig. 8D).

Epimeral plates 1 strongly angular, epimeral plates 2 and 3 slightly pointed, all with strong corner spine-like seta and several posterior lateral setae. Epimeral plates 2 and 3 with 3 subventral spines each (fig. 8C).

Head with short rostrum and subrounded lateral cephalic lobes, ventroanterior sinus developed; eyes absent (fig. 4E). Antenna 1 reaching half of body, peduncular articles 1-3 progressively shorter (ratio: 50:43:20), bearing several shorter setae each (fig. 4F). Main flagellum consisting of 21 articles (most of them with one short aesthetasc); accessory flagellum short, 2-articulated (fig. 4F). Antenna 2: peduncular article 3 with distal bunch of setae longer than diameter of article itself; article 4 slightly longer than article 5 (ratio: 75:65), along dorsal margin with short setae, along ventral margin with 2 bunches of setae (the longest setae remarkably exceeding diameter of article itself); article 5 along dorsal margin with 4 groups of short setae, along ventral margin with 3 bunches of long setae (fig. 4G); flagellum slender, consisting of 9 articles bearing short setae. Antennal gland cone relatively short (fig. 4G). 


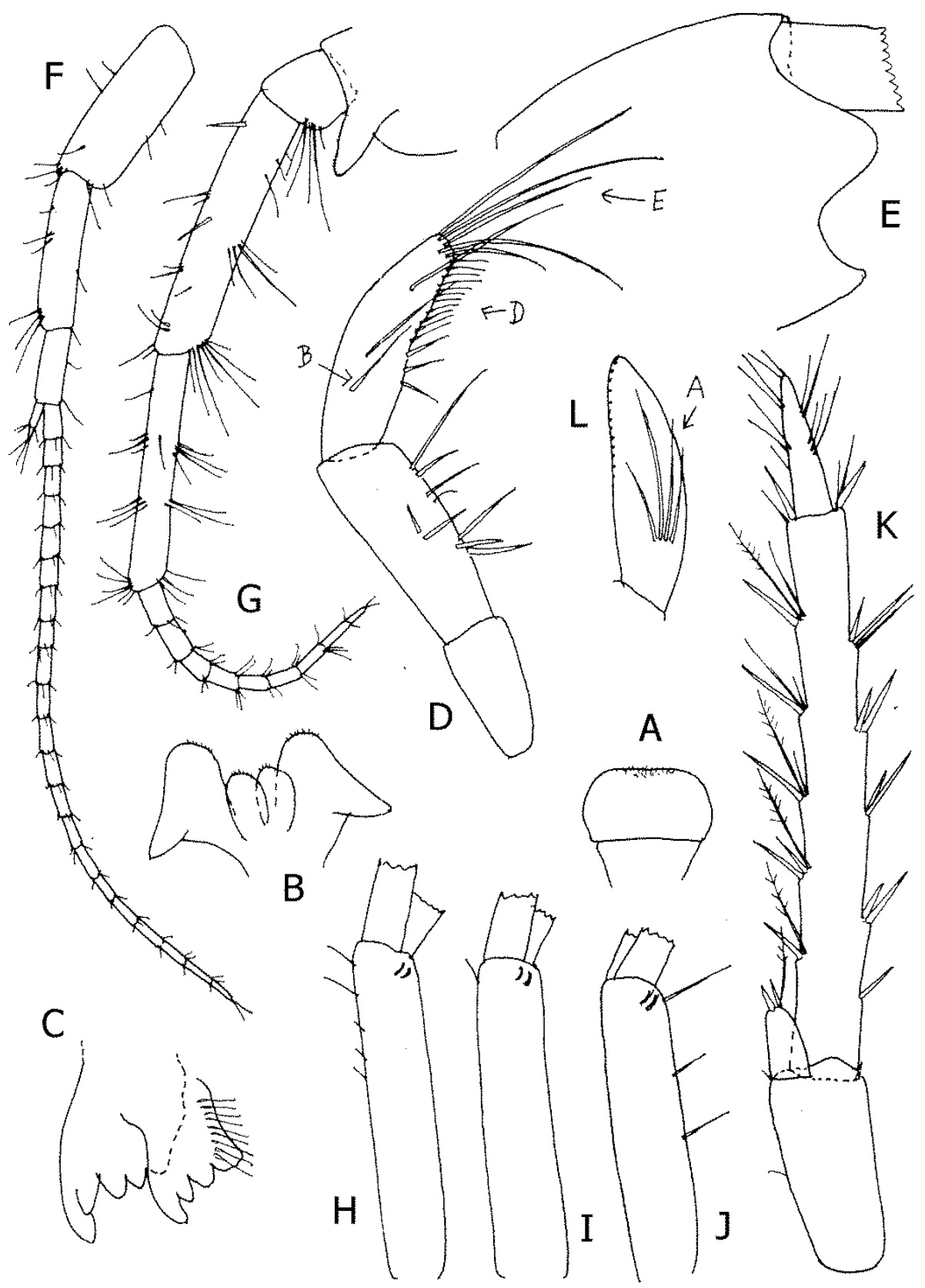

Fig. 4. Niphargus pararhodi, sp. n., Spring-brook along river Goudouras, male $8.2 \mathrm{~mm}$ : A= labrum; $\mathrm{B}=$ labium; $\mathrm{C}=$ left mandible: incisor and lacinia mobilis; $\mathrm{D}=$ mandibular palpus, inner face, with $\mathrm{B}, \mathrm{D}$ and $\mathrm{E}$ setae; $\mathrm{E}=$ head; $\mathrm{F}=$ antenna 1 ; $\mathrm{G}=$ antenna 2; $\mathrm{H}=$ pleopod 1 peduncle; $\mathrm{I}=$ pleopod 2 peduncle; $\mathrm{J}=$ pleopod 3 peduncle; $\mathrm{K}=$ uropod 3; L= last article of mandibular palpus, outer face with Asetae. 


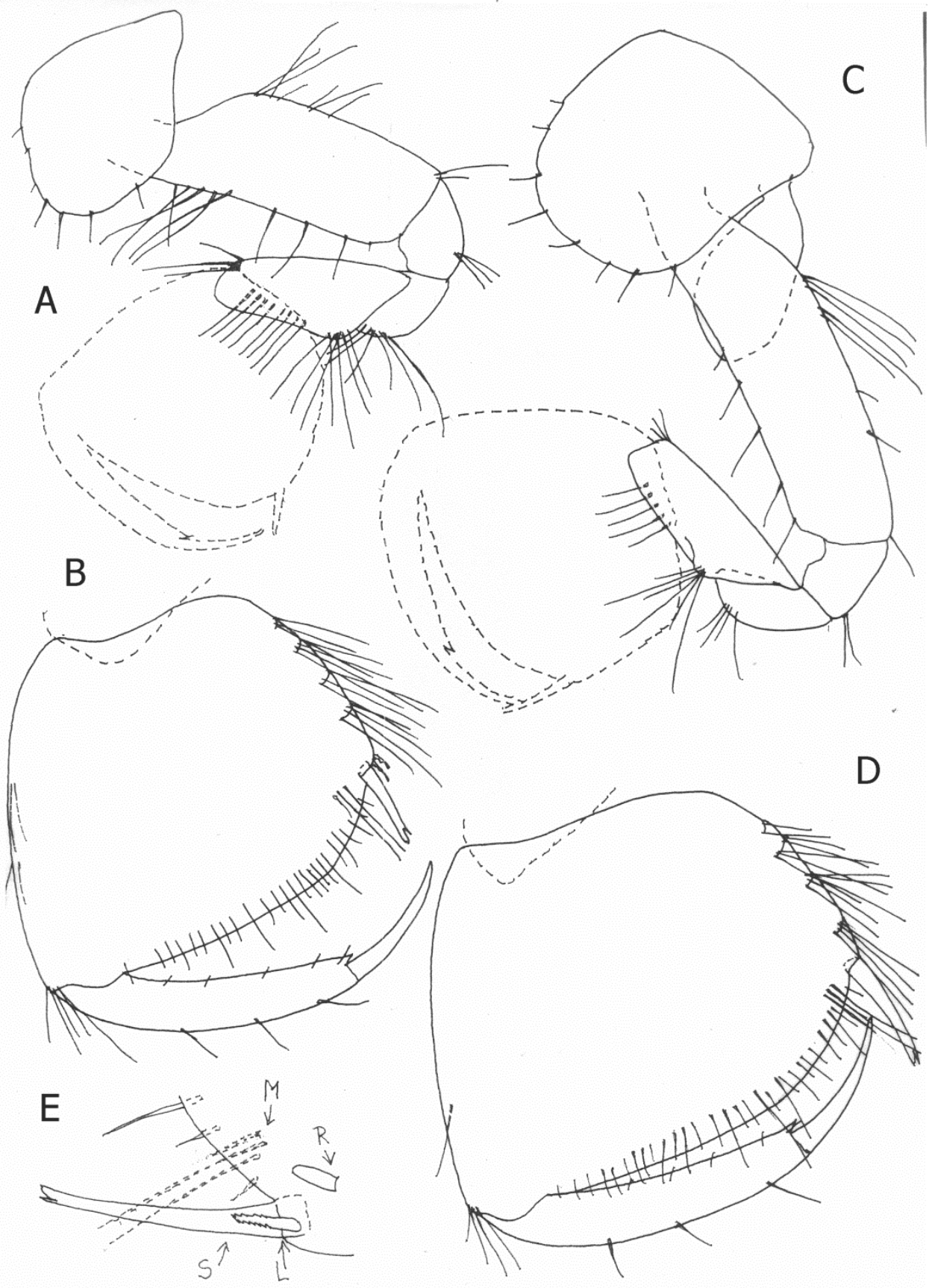

Fig. 5. Niphargus pararhodi, sp. n., Spring-brook along river Goudouras, male $8.2 \mathrm{~mm}$ : A-B= gnathopod 1; C-D= gnathopod 2; $\mathrm{E}=$ distal corner of gnathopod 2 propodus, inner face with $\mathrm{S}, \mathrm{R}, \mathrm{L}$ spines and M-setae. 


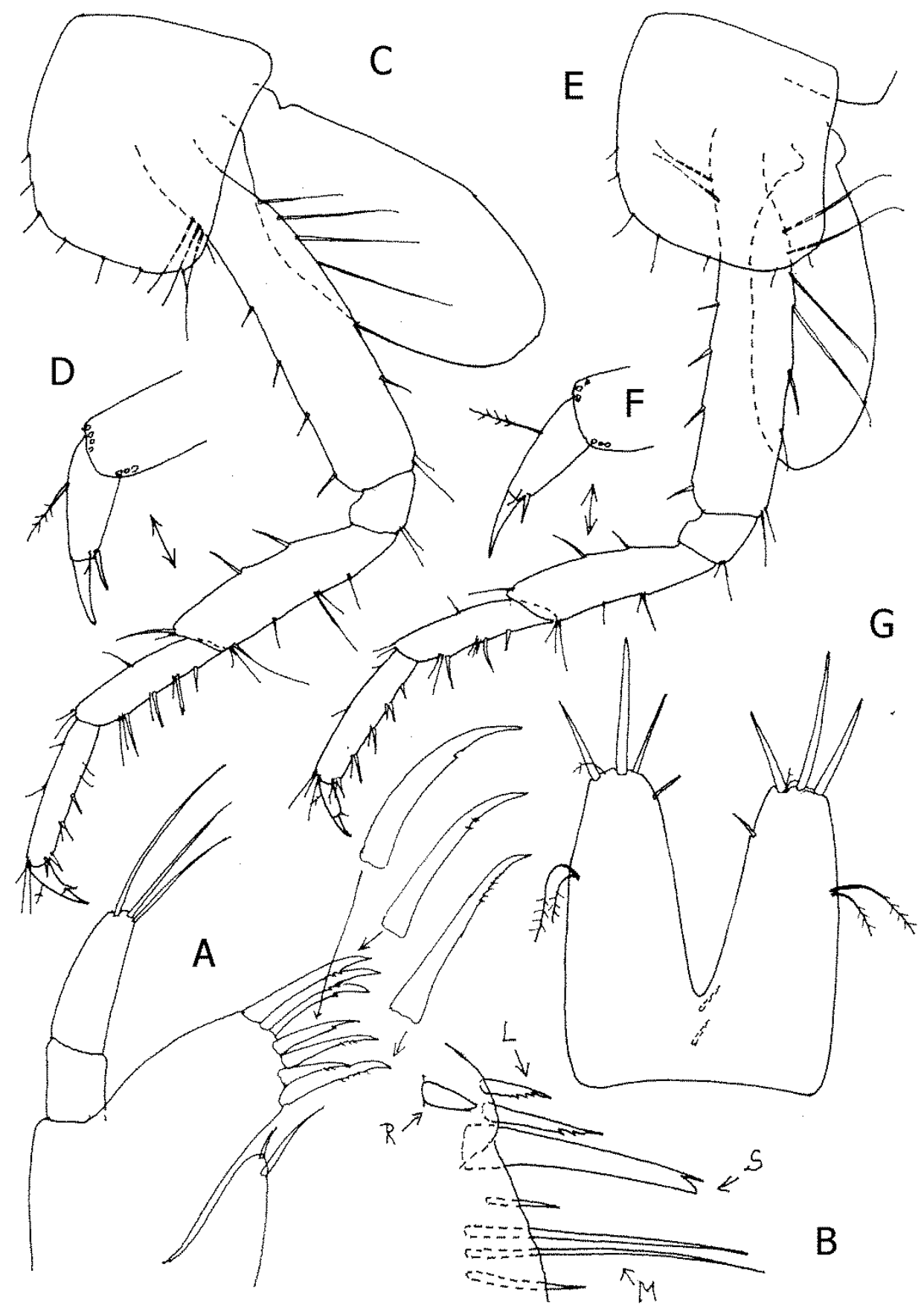

Fig. 6. Niphargus pararhodi, sp. n., Spring-brook along river Goudouras, male $8.2 \mathrm{~mm}$ : $\mathrm{A}=$ maxilla $1 ; \mathrm{B}=$ distal corner of gnathopod 1 propodus, inner face, with R, S, L-spines and M-setae; C-D= pereopod 3, outer face; E-F= pereopod 4, outer face; $\mathrm{G}=$ telson. 


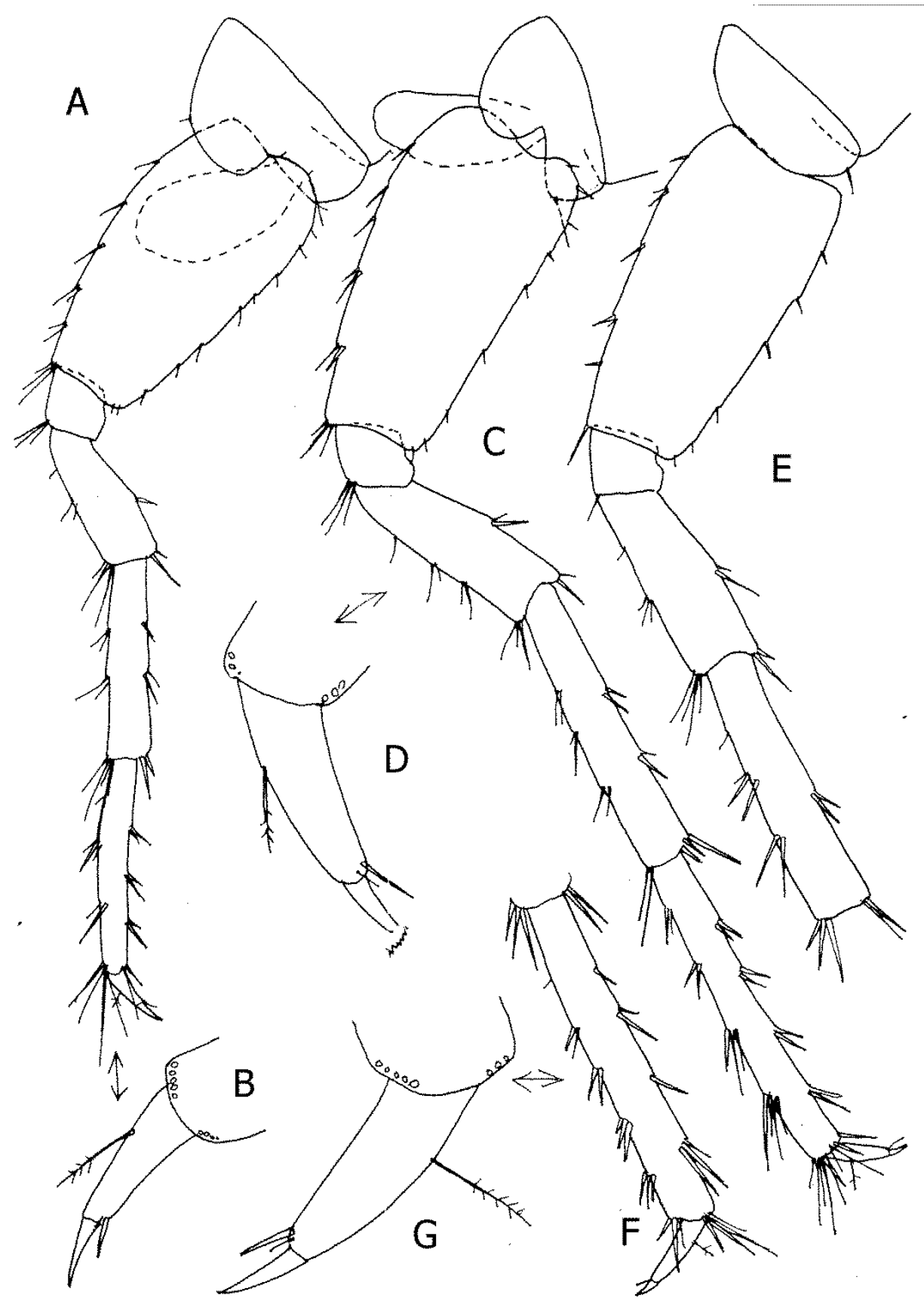

Fig. 7. Niphargus pararhodi, sp. n., Spring-brook along river Goudouras, male $8.2 \mathrm{~mm}$ : A-B= pereopod 5; C-D= pereopod 6; E-F-G= pereopod 7. 


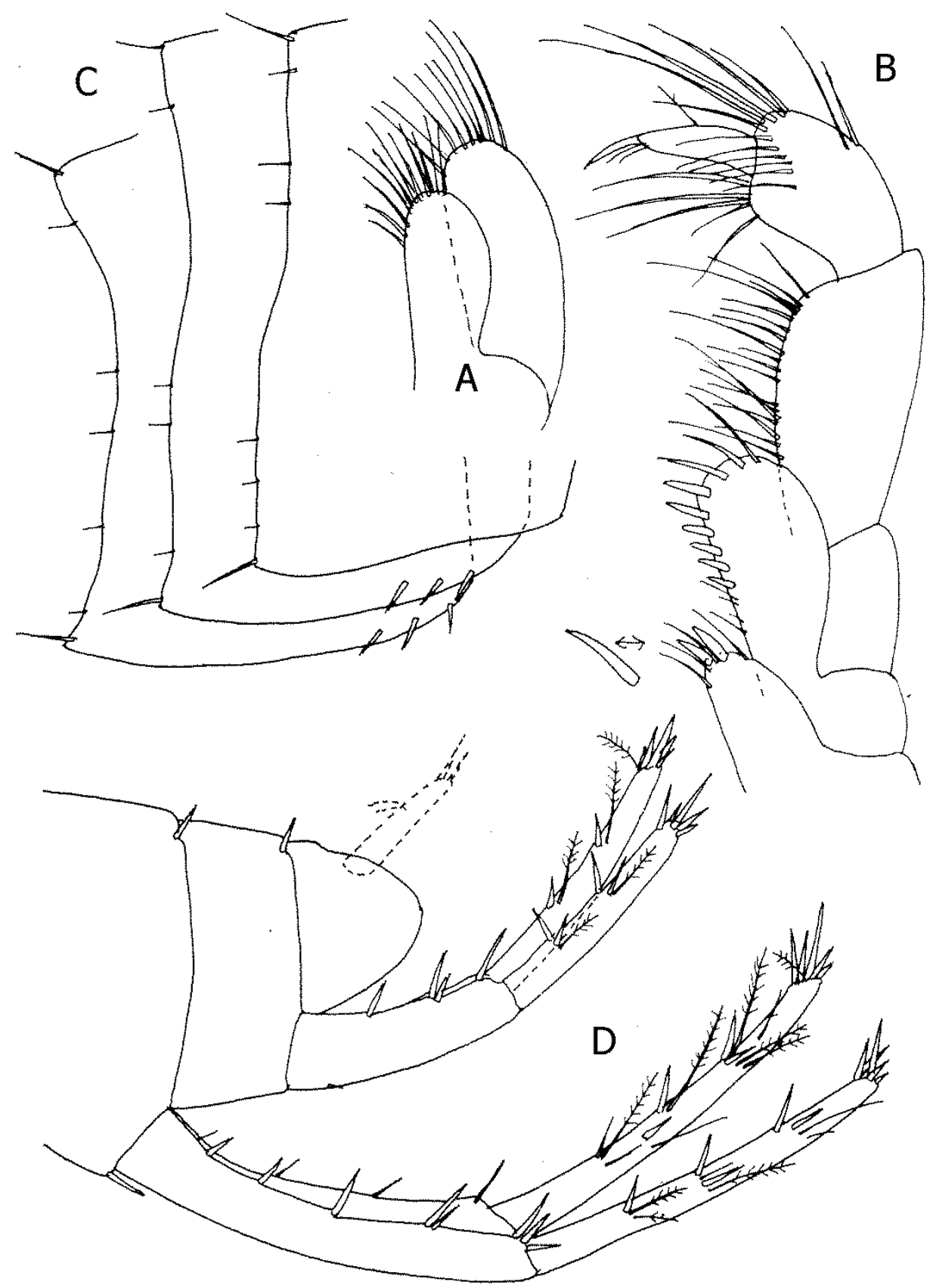

Fig. 8= Niphargus pararhodi, sp. n., Spring-brook along river Goudouras, male $8.2 \mathrm{~mm}$ : A= maxilla 2; $\mathrm{B}=$ maxilliped; $\mathrm{C}=$ epimeral plates 1-3; $\mathrm{D}=$ urosome with uropods 1-2. 
Mouthparts well developed. Labrum much broader than long, with straight to poorly concave distal margin (fig. 4A).

Labium broader than long, with well developed subrounded outer lobes and small inner lobes (fig. 4B).

Mandible with triturative molar. Left mandible: incisor with 5 teeth, lacinia mobilis with 4 teeth and 9 rakers (fig. 4C). Right mandible: incisor with 4 teeth, lacinia mobilis bifurcate, with several teeth and 8 rakers. Mandibular palpus article 1 naked, article 2 with 8 strong spine-like setae (fig. 4D). Palpus article 3 subfalciform, slightly longer than article 2 (ratio: 68:60), provided with nearly 14 D-setae and 5 E-setae, on outer face with one bunch of 4 A-setae (fig. 4L), on inner face with 3 single B-setae (fig. 4D).

Maxilla 1: inner plate with 1-2 unequal setae; outer plate with 7 spines provided with very small, poorly visible lateral teeth each (5-2-3-1-1-2-2; or: 5-23-2-1-3-1); palpus 2-articulated, with 3 long distal setae (fig. 6A).

Maxilla 2: inner plate smaller than outer one, both plates with distomarginal setae (fig. 8A).

Maxilliped: inner plate very short, with 2 distal spines accompanied by several setae (fig. 8B); outer plate short, not reaching half of palpus article 2 and provided with 6-7 distolateral teeth and single setae; palpus article 3 at outer margin with one median and one distal bunch of setae; palpus article 4 at inner margin with 2 setae near basis of nail (fig. 8B).

Coxae relatively short. Coxa 1 hardly broader than long (ratio: 48:44), with broadly subrounded ventroanterior corner and provided with nearly 7 marginal setae (fig. 5A). Coxa 2 slightly longer than broad (ratio: 65:56), broadly subrounded and bearing nearly 8 marginal setae (fig. 5C). Coxa 3 longer than broad (ratio: 65:55), along margin with nearly 8 setae (fig. 6C). Coxa 4 slightly longer than broad (ratio: 60:54), along margin with nearly 7 setae, posterior margin concave, ventroposterior lobe absent (fig. 6E).

Coxae 5-7 are short. Coxa 5 shorter than coxa 4, much broader than long (ratio: 55:32), with one strong ventroposterior corner spine-like seta (fig. 7A). Article above coxa with naked ventroposterior corner (fig. 7A,C,E). Coxa 6 broader than long (ratio: 50:29), with strong ventroposterior spine-like seta (fig. 7C). Coxa 7 shallow, convex ventrally, with ventroposterior corner spine-like seta (fig. 7E).

Gnathopods 1 and 2 are relatively large, with propodus much larger than corresponding coxa (fig. 5A, C). Gnathopod 1: article 2 along anterior margin with long setae, along posterior margin with proximal bunch of longer setae. Article 3 at posterior margin with one distal bunch of setae (fig. 5A); article 5 shorter than propodus (ratio: 48:64), along anterior margin with one distal bunch of setae (fig. 5A). Propodus is only slightly smaller than that of gnathopod 2 (fig. 5B, D), obtusely trapezoid, slightly broader than long (ratio: 100:93), with 4 transverse rows of setae along posterior margin (fig. 5D). Palm convex, inclined nearly 3/5 of propodus-length, defined on outer face by one S-spine accompanied laterally by 2 serrate L-spines and 3 facial M-setae (fig. 5B), on inner face by one 
subcorner R-spine (fig. 6B). Dactylus reaching posterior margin of propodus, along outer margin with 3 median setae, along inner margin with 5 short setae (fig. 5B).

Gnathopod 2: article 2 along anterior margin with row of shorter setae, along posterior margin with 3 long proximal setae and 2 short marginal setae; article 3 with one distal bunch of setae at posterior margin; article 5 slightly elongated, but shorter than propodus (ratio: 55:65) (fig. 5D), along anterior margin with one distal group of setae. Propodus broadly trapezoid, broader than long (ratio: 114:99), along posterior margin with 4 transverse rows of setae (fig. 5D). Palm convex, inclined 2/3 of propodus-length, defined on outer face by one corner S-spine accompanied by one L-spine sitting behind S-spine and with 3 facial M-setae (fig. 5E), on inner face by one subcorner R-spine. Dactylus reaching posterior margin of propodus, along outer margin with 3 median setae, along inner margin with nearly 5 short setae (fig. 5D).

Pereopods 3-4 moderately slender.Pereopod 3: article 2 along anterior margin with 3 proximal long setae and 4 distal short spine-like setae, along posterior margin are attached 4 long proximal setae and 3-4 setae in distal part. Articles 4-6 of unequal length (ratio: 57:38:40); article 4 at posterior margin with several setae (the longest setae exceeding diameter of article itself), along anterior margin with 4 short spine-like setae (fig. 6C); article 5 along posterior margin with 4 strong slender spines accompanied by 2 setae; article 6 along posterior margin with 5 groups of single or paired short spines and setae. Dactylus short and strong, much shorter than article 6 (ratio: 19:40), at inner margin with one spine near basis of the nail, along outer margin with one median longer plumose seta (fig. 6D), nail is much shorter than pedestal (ratio: 17:32).

Pereopod 4: article 2 along anterior margin with 2 long proximal setae and 4 short spine-like setae in distal part of article, along posterior margin are attached 4 long setae in proximal part and 4 strong spine-like setae in distal part of article. Articles 4-6 of unequal length (ratio: 46:38:40); article 2 at posterior margin with 3 groups of setae (the longest setae nearly reaching diameter of article). Article 5 along posterior margin with 3 spines mixed with single short setae; article 6 along posterior margin with 5 bunches of short spines and single setae (fig. 6E). Dactylus strong, much shorter than article 6 (ratio: 17:40), at inner margin with one spine near basis of the nail (fig. 6F), along outer margin with one median plumose seta; nail is shorter than pedestal (ratio: 18:30).

Pereopod 5 distinctly shorter than pereopods 6 and 7, with article 2 elongated, much longer than broad (ratio: 82:45), along anterior margin with row of 6 groups of spine-like setae, along posterior almost straight margin with nearly 11 setae, ventroposterior lobe not developed (fig. 7A). Articles 4-6 of unequal length (ratio: 40:53:56); article 5 along posterior margin with 2 groups of short spines; article 6 along posterior margin with 3 groups of short spines, along anterior margin with 3 groups of setae; article 6 along both margins with 4 bunches of spines mixed with single short setae and with distal bunch of longer spine and setae. Article 2 remarkably longer than article 6 (ratio: 82:56). 
Dactylus much shorter than article 6 (ratio: 21:56), at inner margin with one slender spine near basis of the nail, along outer margin with one median plumose seta (fig. 7B); nail shorter than pedestal (ratio: 19:41).

Pereopod 6: article 2 narrowed, much longer than broad (ratio: 93:47), along anterior margin with 6 groups of spine-like setae, along posterior straight margin with nearly 9 slender and strong setae, ventroposterior lobe not developed (fig. 7C). Articles 4-6 of unequal length (ratio: 57:79:89); article 4 at anterior margin with 4 groups of short setae, along posterior margin with 2 spines; articles 5 and 6 along both margins with bunches of spines mixed with simple setae; article 2 only poorly longer than article 6 (ratio: 93:89). Dactylus much shorter than article 6 (ratio: 23:89), at inner margin with slender spine near basis of the nail, on outer margin with one median plumose seta; nail much shorter than pedestal (fig. 7D).

Pereopod 7: article 2 narrowed, much longer than broad (ratio: 89:45), along anterior poorly convex margin with 6 groups of spine-like setae, along posterior margin with 7 setae or spine-like setae, ventroposterior lobe not developed (fig. 7E). Articles 4-6 of unequal length (ratio: 55:73:94); article 2 with setae along anterior margin and spines along posterior margin (fig. 7F); articles 5 and 6 along both margins with bunches of short spines mixed sometimes with single short seta. Article 2 slightly shorter than article 6 (89:94). Dactylus much shorter than article 6 (ratio: 22:94), at inner margin with slender spine near basis of the nail, at outer margin with one longer median plumose seta (fig. 7G); nail much shorter than pedestal (ratio: 25:65).

Pleopods 1-3 with 2 retinacula each. Peduncle of pleopod 1 along anterior margin with 5 slender setae (fig. $4 \mathrm{H}$ ); peduncle of pleopod 2 naked (fig. $4 \mathrm{I}$ ); peduncle of pleopod 3 along posterior margin with 3 strong setae (fig. 4J).

Uropod 1: peduncle with dorsoexternal row of spines and dorsointernal row of setae (except distal spine) (fig. 8D), ventrodistal tubercle absent. Outer ramus slightly shorter than peduncle, provided with 3 bunches of strong lateral spines mixed with single or paired long plumose setae, and 2-3 simple setae, at tip appears a bunch of 5 short spines (fig. 8D). Inner ramus as long as outer ramus, provided with 4 lateral and 5 distal short spines, 4 groups of 1-4 marginal plumose setae and 3 short simple setae (fig. 8D).

Uropod 2: peduncle provided with lateral and distal strong spines; inner ramus is slightly longer than peduncle, provided with 2 lateral spines accompanied by 2 long plumose setae (fig. 8D), with distal bunch of 5 spines and one plumose seta. Outer ramus slightly shorter than inner ramus, bearing 2 bunches of lateral spines and 2 plumose setae, at tip with bunch of 5 spines (fig. 8D).

Uropod 3 slender: peduncle much longer than broad (ratio: 56:26); inner ramus very short, scale-like, provided with one distal spine and short seta, and with one long plumose seta (fig. 4K). Outer ramus 2-articulated: first article along inner (mesial) margin with 6 groups of spines shorter or longer than diameter of the article itself, accompanied by short simple and long plumose seta 
each; along outer margin of article 1 are attached 6 groups of unequally long spines accompanied sometimes with single simple seta. Second article is much shorter than first one (ratio: 38:150), along both margins with 2-3 bunches of simple setae, at tip appear 2 short simple setae.

Telson slightly longer than broad (ratio: 85:71), slightly gaping, incised almost 3/4 of telson length; each lobe with 3 distal spines and one small spine at mesial margin (fig. 6G); a pair of longer plumose setae is attached rather above half of telson-length.

Coxal gills ovoid, rather elongated on pereopods 3 and 4 (fig. 6C, E), and shorter on gnathopod 2 and pereopods 5 and 6 (figs. 5C, 7A, C).

HOLOTYPE: Male $8.2 \mathrm{~mm}$. Holotype [3 slides: S-7385A/6, 7385A/7, 7385A/8] is deposited in KARAMAN`s Collection in Podgorica, Montenegro.

DERIVATIO NOMINIS. The name "pararhodi" is made according to the rather similarity with Niphargus rhodi.

\section{REMARKS AND AFFINITIES.}

The studied male $8.2 \mathrm{~mm}$ of $N$. pararhodi differs from all other known Niphargus species from Greece by presence of plumose setae on rami of uropods 1 and 2. This character was observed in several Niphargus species belonging to the subgenus Orniphargus S. Karaman 1950 [typus subgeneris: Niphargus orcinus Joseph, 1869] (Karaman, S. 1950a, 1950b) from Bosnia and Herzegovina and Montenegro: N. vjetrenicensis S. Karaman 1932, N. podgoricensis S. Karaman 1934, N. hercegovinensis S. Karaman 1950a, N. kusceri S. Karaman 1950a, N. bilecanus S. Kar. 1953, N. trullipes Sket 1958. Plumose setae on uropods 1 and 2 appear always in males and females of these species (G. Karaman, 1984). Niphargus pararhodi differs distinctly from all these species by combination of various morphological characters.

The members of subgenus Orniphargus in Macedonia ( $N$. macedonicus S. Karaman 1929, N. pellagonicus S. Karaman 1943) and Greece (N. lindbergi S. Karaman 1956 and $N$. lourensis Fišer, Trontelj \& Sket 2006) have rami of uropods 1 and 2 without plumose setae.

In general, the significant character of the subgenus Orniphargus is the absence or remarkable sexual dimorphic differences (between males and females), short distal article of uropod 3 outer ramus and short spiniferous uropod 3 and spiniferous peduncle of uropod 1. Absence of significant morphological differences between males and females is present also within the members of the subgenus Jovaniphargus S. Karaman 1960 (typus subgeneris: Niphargus jovanovici S. Karaman 1931) and Protoniphargopsis Sket 1957 (typus subgeneris: Niphargus kochianus Bate 1859), although these subgenera are created based on external morphological taxonomic characters. 
$N$. pararhodi differs from $N$. lindbergi also by different number of ventroposterior spines on urosomite 1 , by lower number of retinacula on pleopods 1-3, lower number of setae on inner plate of maxilla 1 , etc.

$N$. lourensis differs from $N$. pararhodi also by higher number of setae on maxilla 1 inner plate, by different armature of telson, by presence of dorsointernal row of spines on uropod 1-peduncle, etc. But, despite some similarities, $N$. pararhodi probably don`t belong to Orniphargus group.

N. pararhodi is also similar to Niphargus rhodi S. Karaman 1950 [loc. typ.: source Nimpha on Propheta Mt. (Eliasberg?) Mt., Rhodos Island, Greece], mentioned later in numerous localities of Rhodos island, including Goudouras region (G. Karaman 2017b) by various characters (uropod 3, pereopods, etc.).

The adult females and juv. males of $N$. rhodi of Rhodos island (G. Karaman, 2017b) differ distinctly from $N$. pararhodi by absence of plumose setae on uropods 1 and 2, by higher number of distal setae on maxilla 1 palpus, by subequal plates of maxilla 2, by angular epimeral plates, by different shape of gnathopods 1-2 bearing higher number of transverse rows of setae on propodus, gnathopod 2 propodus with $2 \mathrm{~L}$-spines sitting laterally from S-spine.

It remains theoretical possibility that $N$. pararhodi should be the unknown male of $N$. rhodi, but we have not enough data to consider $N$. pararhodi as conspecific with $N$. rhodi. Further research on new material from Rhodos Island will put more light on the taxonomic status of both species.

\section{ACKNOWLEDGEMENTS.}

I am thankful to Prof. Dr. Giuseppe Pesce from Aquilla (Italy) for the part of material used in this study.

\section{REFERENCES}

Fišer, C., Trontelj, P. \& Sket, B. 2006. Phylogenetic analysis of the Niphargus orcinus species-aggregate (Crustacea: Amphipoda: Niphargidae) with description of new taxa.- Journal of Natural History, 40 (41-43): 2265-2315.

Karaman, G. 1969. XXVII. Beitrag zur Kenntnis der Amphipoden. Arten der Genera Echinogammarus Stebb. und Chaetogammarus Mart. an der jugoslawischer Adriaküste.- Glasnik Republičkog zavoda za zaštitu prirode i Prirodnjačke zbirke u Titogradu, 2: 59-84, 51 figs.

Karaman, G. 1984. Revision of the Niphargus orcinus-Group , Part. I. (Fam. Niphargidae) (Contribution to the Knowledge of the Amphipoda 130).- Glasnik Odjeljenja prirodnih nauka, Crnogorska akademija nauka i umjetnosti, Titograd, 4: 7-79, figs. I-XXXII.

Karaman, G. 2012. Further investigations of the subterranean genus Niphargus Schiödte, 1849 (fam. Niphargidae) in Serbia. (Contribution to the Knowledge of the Amphipoda 264).- Agriculture and Forestry, Podgorica, 58 (2): 45-64; 7 figs.

Karaman, G. 2017a. A new member of the genus Niphargus Schiödte, 1849 (Amphipoda Gammaridea, fam. Niphargidae) from Crete Island, Greece (Contribution to the Knowledge of the Amphipoda 293).-Ecologica Montenegrina, Podgorica, 10: 1-10, 4 figs. 
Karaman, G. 2017b. New data of the subterranean species Niphargus rhodi S. Karaman, 1950 (fam. Niphargidae) In Rhodos island, Greece (Contribution to the Knowledge of the Amphipoda 296).- Agricultura and Forestry, Podgorica, 63 (2): 5-24, figs. 18.

Karaman, S. 1929. Beiträge zur Kenntnis der Amphipoden Jugoslawiens.-Zoologischer Anzeiger, Leipzig, 85 (9/10): 218-225, figs. 1-4.

Karaman, S. 1932. 5. Beitrag zur Kenntnis der Süsswasser-Amphipoden (Amphipoden unterirdischer Gewässer).- Prirodoslovne razprave, Ljubljana, 2: 179-232.

Karaman, S. 1934. VI. Beitrag zur Kenntnis jugoslawischer Süsswasseramphipoden.Zoologischer Anzeiger, Leipzig, 107 (11/12): 325-333, figs. 1-4.

Karaman, S. 1943. Die unterirdischen Amphipoden Südserbiens.-Srpska Kraljevska Akademija, Posebna izdanja, knj. 135, Prirodnjački i matematički spisi, knj. 34, Ohridski Zbornik, Beograd, 4: 1-312, figs. 1-215.

Karaman, S. 1950a. Podrod Orniphargus u Jugoslaviji. I. deo (=Das Subgenus Orniphargus in Jugoslavien, Teil I.).- Srpska Akademija Nauka, Posebna Izdanja knj. 158, Odelenje Prirodno-matematičkih nauka, Beograd, 2: 119-136, 145-156, 160-167, figs. 1-61.

Karaman, S. 1950b. Podrod Orniphargus u Jugoslaviji. II deo (=Das Subgenus Orniphargus in Jugoslavien, Teil II.).- Srpska Akademija Nauka, Posebna Izdanja knj. 158, Odelenje Prirodno-matematičkih nauka, Beograd, 2: 137-146, 156-159, 168-174, figs. 62-82.

Karaman, S. 1953. Über subterrane Amphipoden und Isopoden des Karstes von Dubrovnik und seines Hinterlandes.- Acta, Musei Macedonici Scientiarum Naturalium, Skopje, 1 (7): 137-167, 47 figs.

Karaman, S. 1956. III. Beitrag zur Kenntnis griechischer Niphargiden. - Folia Balcanica, Zavod za Ribarstvona N. R. Makedonija, Skopje, 1 (1): 1-8, figs. 1-9.

Karaman, S. 1960A. Weitere Beiträge zur Kenntnis der Jugoslavischen Niphargiden.Glasnik Prirodnjačkog Muzeja Beograd, Ser. B, 15: 75-90, figs. 1-19.

Ntakis, A., Anastasiadou, C., Zakšek, V. \& Fišer, C. 2015. Phylogeny and biogeography of three new species of Niphargus (Crustacea: Amphipoda) from Greece.Zoologischer Anzeiger 255: 32-46, 16 figs.

Pesce, G.L. \& Maggi, D. 1983. Ricerche faunistiche in acque sotterranee freatiche della Grecia Meridionale ed insulare e stato attuale delle conoscenze sulla stygofauna di Grecia. - Natura, Milano, 74 (1-2): 15-73.

Sket, B. 1957.Über Zoogeographie und Phylogenie der Niphargen.- Verhandlungen der Deutschen Zoologischen Gesellschaft in Graz 1957, pp. 484-486.

Sket, B. 1958. Einige interessante Funde der Malacostraca (Crust.) aus der Herzegowina und Crna Gora. - Bulletin Scientifique, 4 (2): 53, figs. 1-3. 